\title{
Erratum to: The effect of light and nutrient availability on growth, nitrogen, and pigment contents of Saccharina latissima (Phaeophyceae) grown in outdoor tanks, under natural variation of sunlight and temperature, during autumn and early winter in Denmark
}

Teis Boderskov ${ }^{1}$ - Peter Søndergaard Schmedes ${ }^{1}$ - Annette Bruhn ${ }^{1}$. Michael Bo Rasmussen ${ }^{1}$ • Mette Møller Nielsen ${ }^{1}$ - Morten Foldager Pedersen ${ }^{2}$

Published online: 29 August 2015

(C) Springer Science+Business Media Dordrecht 2015

Erratum to J Appl Phycol

DOI 10.1007/s10811-015-0673-7

The name of author Peter Schmedes was incorrect in the original version of this article. The correct authors' list is given above. The original version is also corrected.

2 Department of Environmental, Social and Spatial Change (ENSPAC), Roskilde University, Universitetsvej 1, 4000 Roskilde, Denmark 